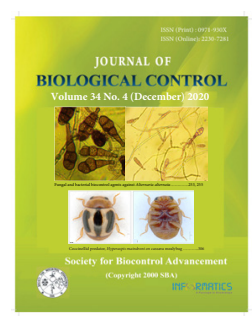

\title{
Record of coccinellid predator, Hyperaspis maindroni Sicard (Coleoptera: Coccinellidae) on invasive cassava mealybug, Phenacoccus manihoti Matile-Ferrero (Hemiptera: Pseudococcidae)
}

\author{
KOLLA SREEDEVI ${ }^{1 *}$, N. V. VEENA ${ }^{1}$, SUNIL JOSHI ${ }^{1 *}$, M. MOHAN ${ }^{2}$, M. SAMPATH KUMAR ${ }^{1}$, G. MAHENDIRAN ${ }^{1}$, \\ T. VENKATESAN ${ }^{2}$, and A. N. SHYLESHA ${ }^{3}$ \\ ${ }^{1}$ Division of Germplasm Collection and Characterization, ${ }^{2}$ Division of Genomic Resources, ${ }^{3}$ Division of Germplasm Conservation \\ and Utilization, ICAR - National Bureau of Agricultural Insect Resources, H. A. Farm post, Hebbal, Bellary Road, Bengaluru \\ - 560024, Karnataka, India \\ *Corresponding authors E-mail: kolla.sreedevi@gmail.com; sunjoshi.pdbc@gmail.com
}

\begin{abstract}
The cassava mealybug, Phenacoccus manihoti Matile-Ferrero is one of the most serious pests of cassava worldwide, which got recently introduced into India (traced in Kerala) as a potential invasive pest. Studies were carried out to record the incidence of mealybug, P. manihoti and its natural enemies on different varieties of cassava in Namakkal dt. of Tamil Nadu during June 2020. The observations were taken in the field in situ as well in the collected mealybug infested twigs in the laboratory. Results revealed that all the three surveyed cassava varieties viz., Mulluvadi, Thailand white and Shree Atulya were found severely infested with cassava mealybug. A huge number of coccinellid beetles were collected from the P. manihoti colonies, which were identified as Hyperaspis maindroni Sicard, 1929 (Coccinellidae: Coccinellinae: Hyperaspidini). Molecular characterization of both grub and adult beetle of $H$. maindroni was carried out to confirm its identity.
\end{abstract}

KEY WORDS: Cassava mealybug, Coccinellidae, Hyperaspis maindroni, Phenacoccus manihoti, predator

(Article chronicle:Received: 25-09-2020; Revised: 11-12-2020; Accepted: 15-12-2020)

\section{INTROUCTION}

Cassava mealybug, Phenacoccus manihoti Matile-Ferrero (Hemiptera: Pseudococcidae) is known to infest mainly cassava and its wild relative, Manihot glaziovii Mull. Arg. The crawlers and the adult mealybugs colonise on the leaves and suck sap causing distortion of the leaves. In severe cases of infestation, the plants show wilting symptoms and exhibit die-back. The mealybug infestation also leads to the development of sooty mould that affects photosynthesis and thereby affecting the yield.

A number of ladybird beetles belonging to Coccinellidae of Coleoptera function as important biocontrol agents of several sucking pests especially mealybugs. Around $90 \%$ of coccinellid species are predacious in nature serving as biocontrol agents (Hodek, 2012). Of several genera of predatory ladybird beetles, Hyperaspis is promising in predating on a wide range of sucking insects. The genus Hyperaspis Chevrolat, 1837 comprises of nearly 400 species worldwide (Kováŕ 2007; Bogaert et al., 2012) that are mainly predators on scale insects, mealybugs and aphids belonging to Hemiptera (Gordon and Canepari, 2008). Several species of Hyperaspis have been successfully introduced into newer areas to attain biological control.

On cassava mealybug, five Hyperaspis spp. were found to predate besides Cyra spp. in Africa. The Hyperaspis spp. got introduced in Africa from South America to control cassava mealybug (Neuenschwander 2001), of which H. notata Mulsant got established in Zaire, Burundi and Mozambique and recovered too from the fields. Similarly, Hyperaspis senegalensis hottentotta Mulsant was found to be the most endemic species on cassava mealybug in the Congo, Central Africa on cassava (Fabres and Kiyindou, 1985).

In South Asia, Hyperaspis maindroni Sicard, 1929 is known to occur widely and is an important species of Hyperaspines. The species predates on wide range of mealybug species viz., Maconellicoccus hirsutus (Green) Phenacoccus solenopsis Tinsley and Saccharicoccus sacchari (Cockerell) (CABI, 2017). Hyperaspis maindroni 
Record of Hyperaspis maindroni on invasive cassava mealybug, Phenacoccus manihoti

got established in India from New Guinea to bring control of hibiscus mealybug (Rao et al., 1971) and found to be widely distributed in South India (Poorani, 2002).

The recent report on the inadvertent entry of cassava mealybug, $P$ manihoti into India during April 2020 (Joshi et al., 2020) has led to a search for its further spread. So, surveys were carried out in neighboring state of Tamil Nadu to record the occurrence of this mealybug on cassava crop and its natural enemies especially coccinellid predator, Hyperaspis sp.

\section{MATERIALS AND METHODS}

The surveys were carried out for cassava mealybug infestation and occurrence of Hyperaspis sp. on cassava plants in Tamil Nadu. The cassava plants belonging to three varieties viz., Mulluvadi, Thailand White and Shree Atulya were observed for mealybug infestation and the associated coccinellid predator (Table 1) in the Namakkal district of Tamil Nadu during June 2020. Data on the incidence of mealybug infestation and the number of coccinellid predator were recorded in the field in situ. Later, the collections of cassava mealybug colonies along with the infested twigs were brought to the laboratory and observed for the occurrence of H. maindroni grubs carefully, which camouflages with the mealybug. The number of grubs and adults of Hyperaspis sp. from each infested twig (of $30 \mathrm{~cm}$ length approximately) were recorded. Likewise 30 infested twigs were observed for the presence of Hyperaspis sp. grubs and adults.

The mealybugs and coccinellid predator were then separated from the cassava twigs and identified. The detailed examination of both grubs and adults of Hyperaspis sp. was carried out and the morphological characters were observed through Stereozoom microscope, Leica M60. Morphometric studies of the coccinellid adults were taken viz., Total length (TL) - from the apex of the clypeus to apical margin of elytra; Total width (TW)-at the widest part of both elytra; Pronotal Length (PL)- from the middle of anterior margin to the pronotal base; Pronotal Width (PW)- at the widest part of the pronotum; Elytral Length (EL)- along the suture from apex to base.

Images of the adult and grub specimens were taken using Leica M 205A having automontage software. Photographs were edited and plates were prepared using Adobe Photoshop 7.0. The identified specimens are deposited in the National Insect Museum, ICAR-National Bureau of Agricultural Insect Resources, Bengaluru, Karnataka, India.

\section{Molecular characterization}

The molecular characterization of both grub and adult of Hyperaspis sp. was carried out through the mitochondrial Cox 1 gene sequencing.

\section{Insect sample collection and preservation}

The adult beetles and grubs of $H$. maindroni collected from Namakkal district of Tamil Nadu were identified taxonomically and used for molecular characterization. Five beetles and grubs were transferred to $100 \%$ ethanol for further processing of DNA extraction and the remaining specimens were kept as voucher specimens as dry collections and alcohol preserved specimens and stored at $20^{\circ} \mathrm{C}$ (Robert, 2002), at the Indian Council of Agricultural ResearchNational Bureau of Agricultural Insect Resources (ICARNBAIR) Bengaluru, India.

\section{DNA extraction}

DNA was extracted from the adult and grub of $H$. maindroni using QiagenDNeasy ${ }^{\circledR}$ kit, following the manufacturer's protocols.

\section{PCR amplification of mitochondrial cytochrome oxidase subunit 1 gene}

The extracts were subjected to PCR amplification of a $658 \mathrm{bp}$ region near the 5' terminus of the cox 1 gene following standard protocol (Hebert et al., 2003). Primers used were: forward primer (LCO 1490: 5' - G G T C A A C A A AT C ATA A A G ATAT T G G - 3' ), and reverse primer (HCO 2198: 5'-TAAACTTCA GGGTGACCAAAAAATCA-3'). PCR reactions were carried out in 96-well plates, $50 \mu \mathrm{L}$ reaction volume containing: $5 \mu \mathrm{L}$ GeNeiTMTaq buffer, $3 \mu \mathrm{L}$ GeNeiTM 10mM dNTP mix, $1 \mu \mathrm{L}(20 \mathrm{pmol} / \mu \mathrm{L})$ forward primer, $1 \mu \mathrm{L}(20 \mathrm{pmol} /$ $\mu \mathrm{L})$ reverse primer, $1 \mu \mathrm{L}$ GeNeiTMTaq DNA polymerase (1 $\mathrm{U} / \mu \mathrm{L}), 8 \mu \mathrm{L}$ DNA $(50 \mathrm{ng} / \mu \mathrm{L})$, and $31 \mu \mathrm{L}$ sterile water. Thermo cycling consisted of an initial denaturation of $94^{\circ} \mathrm{C}$ for $5 \mathrm{~min}$, followed by 34 cycles of denaturation at $94^{\circ} \mathrm{C}$ for $1 \mathrm{~min}$, annealing at $45^{\circ} \mathrm{C}$ for $30 \mathrm{Sec}$ and extension at $72^{\circ} \mathrm{C}$ for $1 \mathrm{~min}$. PCR was performed using a BioRad C1000 Thermal Cycler. The amplified products were analyzed on a $1.5 \%$ agarose gel electrophoresis as described by Sambrook and Russell (2001). The amplified products were sequenced by $\mathrm{M} / \mathrm{s}$ Barcode Bioscience, Bengaluru. The COI generated sequences have been deposited in NCBI Genbank database.

\section{RESULTS AND DISCUSSION}

All three varieties of cassava viz., Mulluvadi, Thailand white and Shree Atulya were found to be severely infested with cassava mealybug in Namakkal dt. of Tamil Nadu. Surveys revealed heavy infestation of mealybugs on cassava plants and associated population of coccinellid predator adults and grubs feeding on the mealybugs (Table 1). The collected mealybug was identified and confirmed as $P$. manihoti and the coccinellid beetles as $H$. maindroni. 


\section{Abundance of $\boldsymbol{H}$. maindroni in cassava mealybug colonies}

Around 20-25 cassava mealybug infested twigs from the infested cassava fields were assessed for the cassava mealybug population density (number of adults and active crawlers) and its coccinellid predator, $H$. maindroni. Around 14 to 35 adult beetles of $H$. maindroni were found per infested twig in all the surveyed areas of Namagiripettai and Sendamangalam blocks of Namakkal district of Tamil Nadu. The cassava fields in Pottanam region of Sendamangalam block exhibited highest H. maindroni population (34.7 \pm 3.5$)$ (Table 1).

The lab studies also revealed the occurrence of $H$. maindroni grubs and adults in the cassava mealybug colonies. The adults of $H$. maindroni ranged from 4 to 24 per mealybug infested twig while grubs ranged from 11 to 39 grubs per infested twig (Table 2).

\section{Morphological characters}

The adult beetle of $H$. maindroni is oval bodied, head and pronotum yellow, elytra pale yellow with three longitudinal black stripes: two black stripes in a mid-dorsal position on each elytron, not reaching both the basal or apical margins and a sutural stripe reaching apex (Fig. 1A). All legs yellow and ventral body yellow to orange coloured (Fig. 1B). The morphometrics of the adult beetles of $H$. maindroni presented in Table 3 . The total length (TL) ranged from 2.8 to $3.1 \mathrm{~mm}$ with a mean of 2.95 , total width (TW) ranged from 2.12 to $2.16 \mathrm{~mm}$ with a mean of $2.14 \mathrm{~mm}$, pronotal length (PL) ranged from 0.68 to $0.75 \mathrm{~mm}$ with a mean of $0.71 \mathrm{~mm}$, pronotal width (PW) ranged from 1.68 to $1.72 \mathrm{~mm}$ with a mean of $1.69 \mathrm{~mm}$, elytral length (EL) ranged from 2.09 to $2.15 \mathrm{~mm}$ with a mean of $2.11 \mathrm{~mm}$ (Table 3 ).

The grub of $H$. maindroni is stout, light yellowish brown, segmented body (Fig. 1C, D) absolutely camouflaging with the mealybug with its mealy coat on dorsum.

Table 1. Population density of cassava mealybug, $P$. manihoti and its coccinellid predator, $H$. maindroni in the field

\begin{tabular}{|c|l|c|c|}
\hline $\begin{array}{l}\text { Sample } \\
\text { No }\end{array}$ & Details of collection site & $\begin{array}{c}\text { Mealybug/twig } \\
\text { Mean+SE }\end{array}$ & $\begin{array}{c}\text { Hyperaspis maindronil } \\
\text { twig (Mean+SE) (n=30) }\end{array}$ \\
\hline 1. & $\begin{array}{l}\text { Pachudayampalayam, Namagiripettai Block, Namakkal } \\
\text { Dt., Tamil Nadu }\end{array}$ & $373.5 \pm 7.2$ & $33.6 \pm 2.1$ \\
\hline 2. & $\begin{array}{l}\text { Perumagoundampalayam, Namagiripettai Block, } \\
\text { Namakkal Dt., Tamil Nadu }\end{array}$ & $459.8 \pm 13.5$ & $18.6 \pm 1.3$ \\
\hline 3. & $\begin{array}{l}\text { Oduvankurichi, Namagiripettai Block, Namakkal Dt., } \\
\text { Tamil Nadu }\end{array}$ & $389.6 \pm 3.3$ & $13.6 \pm 0.9$ \\
\hline 4. & $\begin{array}{l}\text { Thoppapatti, Namagiripettai Block, Namakkal Dt., } \\
\text { Tamil Nadu }\end{array}$ & $223.3 \pm 9.6$ & $26.9 \pm 2.3$ \\
\hline 5. & $\begin{array}{l}\text { T. Jedarpalayam, Namagiripettai Block, Namakkal Dt., } \\
\text { Tamil Nadu }\end{array}$ & $259 \pm 14.5$ & $17.5 \pm 1.0$ \\
\hline 6. & $\begin{array}{l}\text { Kalkurichi, Sendamangalam Block, Namakkal Dt., } \\
\text { Tamil Nadu }\end{array}$ & $412.8 \pm 11.3$ & $34.7 \pm 3.5$ \\
\hline 7. & $\begin{array}{l}\text { Pottanam, Sendamangalam Block, Namakkal Dt., } \\
\text { Tamil Nadu }\end{array}$ & $601 \pm 23.8$ & $29.4 \pm 2.9$ \\
\hline 8. & $\begin{array}{l}\text { Belukurichi, Sendamangalam Block, Namakkal Dt., } \\
\text { Tamil Nadu }\end{array}$ & $442 \pm 17.4$ & \\
\hline
\end{tabular}

Table 2. Occurrence of H. maindroni in the cassava mealybug colonies collected from Namakkal district of Tamil Nadu (in the laboratory)

\begin{tabular}{|c|c|c|c|c|}
\hline S. No. & Mealybug infestation & $\begin{array}{l}\text { No. of samples } \\
\text { examined }\end{array}$ & $\begin{array}{l}\text { No. of } \boldsymbol{H} \text {. maindroni } \\
\text { beetles }\end{array}$ & $\begin{array}{l}\text { No. of } \boldsymbol{H} \text {. maindroni } \\
\text { grubs }\end{array}$ \\
\hline 1. & I & 30 & 4 & 11 \\
\hline 2. & II & 30 & 7 & 12 \\
\hline 3. & III & 30 & 24 & 17 \\
\hline 4. & III & 30 & 16 & 22 \\
\hline 5. & III & 30 & 18 & 31 \\
\hline 6. & III & 30 & 8 & 14 \\
\hline 7. & II & 30 & & \\
\hline
\end{tabular}

Grade I-Sparse incidence on cassava twig (of $30 \mathrm{~cm}$ length); Grade II - Medium incidence on the twig; Grade III - Severe incidence on the twig 


\section{Molecular characterization}

The mitochondrial gene sequencing of adult and grubs confirmed the identity of coccinellid predator, H. maindroni and the accession numbers obtained (MT679210 for grub and MT679211 for adult) were submitted to NCBI database and BOLD. The barcodes were generated for the same.

In natural unsprayed cassava fields, $H$. maindroni was found associated with the mealybug, $P$. manihoti colonies effecting the biological control. The field surveys revealed that the species $H$. maindroni was the abundant coccinellid species found in the mealybug colonies. It is reported to be distributed widely in India and Pakistan (Poorani, 2002). Sankar et al. (2011) recorded the natural incidence of H. maindroni on solenopsis mealybug, P. solenopsis in Permabulur district of Tamil Nadu but was recorded low as compared to the other coccinellid predator, Scymnus nubilus (Mulsant). In the present study, the cassava mealybug samples collected from Namakkal district of Tamil Nadu showed higher percent incidence of $H$. maindroni. Mukherjee and Suman (2017) reported the occurrence of H. maindroni $(1.25 \%)$ in Bhubhaneswar on cowpea and ridge gourd while Poorani and Lalitha (2018) reported its occurrence on M.hirsutus in mulberry.

\section{CONCLUSION}

High incidence of cassava mealy bug, P. manihoti was observed on three varieties, Mulluvadi, Thailand white and Shree Atulya of cassava in the Namakkal district of Tamil Nadu. Occurrence of high number of coccinellid predator, H. maindroni in P. manihoti colonies was recorded, which can naturally bring down the pest population. The natural occurrence of this predator in mealybug colonies implies the need for conservation of the same, the important component
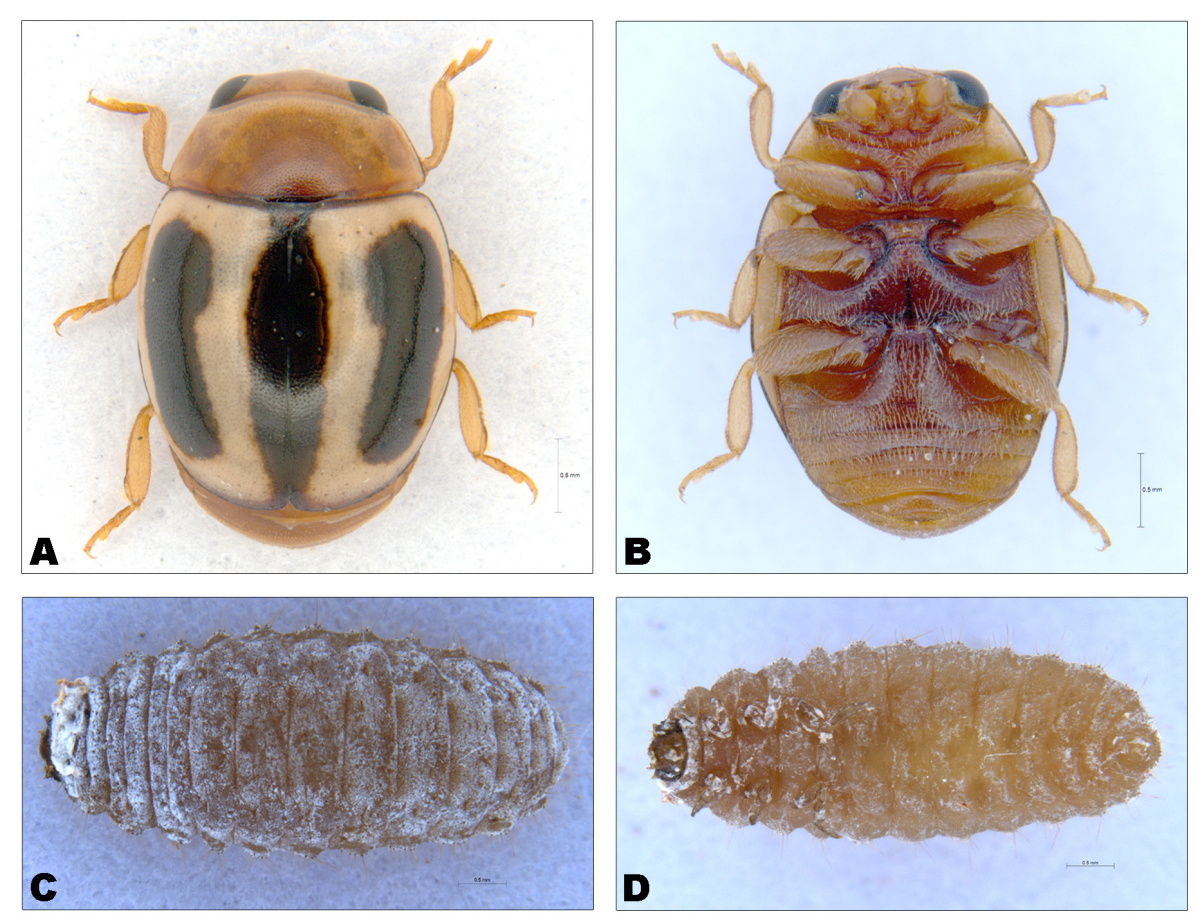

Figure 1. Hyperaspis maindroni A. Adult dorsal view B. ventral view C. Grub dorsal view D. ventral view

Table 3. Measurements of adult beetle of $H$. maindroni

\begin{tabular}{|l|l|l|}
\hline S. No. & Parameter & Mean \pm SE \\
\hline 1. & Total length (TL) & $2.95 \pm 0.06$ \\
\hline 2. & Total width (TW) & $2.14 \pm 0.01$ \\
\hline 3. & Pronotal length (PL) & $0.71 \pm 0.01$ \\
\hline 4. & Pronotal width (PW) & $1.69 \pm 0.02$ \\
\hline 5. & Elytral length (EL) & $2.11 \pm 0.01$ \\
\hline
\end{tabular}


KOLLA SREEDEVI et al.

of the biological control. The farmers should look for this natural predator, $H$. maindroni carefully while taking up the management practices for cassava mealybug as $H$. maindroni grubs camoflagues with the mealybug and becomes difficult to differentiate or identify. The farmers need to be educated to observe for the presence of this coccinellid predator and accordingly plan management strategies.

\section{ACKNOWLEDGEMENT}

Authors are thankful to Dr. N. Bakthavatsalam, Director, ICAR-NBAIR, Bengaluru for facilitating the study.

\section{REFERENCES}

Bogaert J, Adriaens T, Constan J, Lock K, Canepari C. 2012. Hyperaspis ladybirds in Belgium, with the description of H. magnopustulata sp. nov. and faunistic notes (Coleoptera, Coccinellidae). Bull.Soc. R Belge Entomolog. 148:34-41.

CABI. 2017. Datasheet on Hyperaspis maindroni. Available on: http://www.cabi.org/isc/datasheet/27732

Fabres G, Kiyindou A. 1985. Comparaison du potentiel biotique de deux coccinelles (Exochomus flaviventris et Hyperaspis senegalensis hottentotta, Col. Coccinellidae) pre'datrices de Phenacoccus manihoti (Horn. Pseudococcidae) au Congo. Acta Oecol. Oecol. Appl. 6, 339-348

Gordon RD, Canepari C. 2008. South American Coccinellidae (Coleoptera), Part XI: A systematic revision of Hyperaspidini (Hyperaspidinae). Annali del Museo Civico di Storia Naturale “G. Doria”. 99: 245-512.

Hebert PDN, Ratnasingham S, de Waard JR. 2003. Barcoding animal life: Cytochrome $\mathrm{c}$ oxidase subunit 1 divergences among closely related species. Proc Royal Soc London. Series B, Biol Sci. 270: Suppl 1 S96-S99. https://doi.org/10.1098/rsbl.2003.0025 PMid:12952648

Hodek I. 2012. Diapuase/Dormancy. In: Hodek I, van Emden HF, Honěk A (Eds) Ecology and Behaviour of the Ladybird Beetles (Coccinellidae). Blackwell Publishing Ltd., Chich-ester, 275-342. https://doi. org/10.1002/9781118223208.ch6

Joshi S., Pai, S. G. Deepthy K. B. and Ballal C. R. 2020. The cassava mealybug, Phenacoccus manihoti Matile-Ferrero (Hemiptera: Coccomorpha: Pseudococcidae) arrives in India. Zootaxa. 4772(1): 191-194.
Kováŕ I. 2007. Coccinellidae. In: Lobl I, Smetana A (Eds) Catalogue of Palaearctic Coleoptera. Vol. 4. Elateroidea, Derodontoidea, Bostrichoidea, Lymexyloidea, Cleroidea, Cucujoidea . Apollo Books, Stentrup, 71-74, 568-630 pp.

Mukherjee SK, Suman SS. 2017. Coccinellid beetles diversity in agro-climatic zones of Bhubaneswar. $J$ Entomol Zool Stud, 5(4): 1244-1248.

Neuenschwander P. 2001. Biological control of the cassava mealybug in Africa: A review. Biol Control. 21: 214229. https://doi.org/10.1006/bcon.2001.0937

Poorani J. 2002. An annotated checklist of the Coccinellidae (Coleoptera) (excluding Epilachninae) of the Indian subregion. Orient Insects. 36: 307-383. https://doi.org/ 10.1080/00305316.2002.10417335

Poorani J, Lalitha N. 2018. Illustrated accounts of coccinellid predators of Maconellicoccus hirsutus (Green) (Hemiptera: Sternorrhyncha: Pseudococcidae) on mulberry in India, with description of a new species of Scymnus Kugelann (Coleoptera: Coccinellidae) from West Bengal. Zootaxa. 4382 (1): 93-120 https://doi. org/10.11646/zootaxa.4382.1.3 PMid:29689939

Rao VP, Ghani MA, Sankaran T, Mathur XC. 1971. A review of the biological control of insects and other pests in South-east Asia and the Pacific region. Technical Communication No. 6. Trinidad: Commonwealth Institute of Biological Control.

Robert HC. 2002. Molecular markers for the phylogenetics of mites and ticks. Syst Appl Acarol, 7: 3-14. https://doi.org/10.11158/saa.7.1.1

Sambrook JF, Russell DW. 2001. Molecular cloning: A laboratory manual, 3rdedn Cold Spring Harbor Laboratory Press, Cold Spring Harbor, New York, USA. 2100 pp.

Sankar C, Marimuthu R, Saravanan P, Jeyakumar P, Tanwar RK, Sathyakumar S, Bambawale O M, Ramamurthy VV, Barik A. 2011. Predators and parasitoids of cotton mealybug, Phenacoccus solenopsis Tinsley (Hemiptera: Pseudococcidae) in Perambalur district of Tamil Nadu. $J$ Biol Control. 25(3): 242-245.

Sicard A. 1929. XXII - Descriptions de quelques espèces nouvelles de Coccinellides de la faune indo-malaise. J. Nat. Hist. Series 10. 3(14):179-184. 